\title{
Ontological Instability and the Place of the Subject in Contemporary
}

\section{Fiction $^{1}$}

Marco Caracciolo

Ghent University

marco.caracciolo@ugent.be

Pre-print version, please cite published article

In 2008, a group of anthropologists met at the University of Manchester to debate a motion titled "ontology is just another word for culture." Arguing in favor of the motion were Michael Carrithers and Matei Candea, while Karen Sykes and Martin Holbraad were opposing it (see Carrithers et al.). The debate focused on claims made by theorists of the so-called ontological turn in anthropology, notably Eduardo Viveiros de Castro and Holbraad himself. "Ontology" is not an easy word, and the Manchester debate demonstrated how unwieldly ontological claims can be. When Viveiros de Castro argues that the Indigenous peoples of the Amazon have a different ontology from the West, he is obviously not making a metaphysical statement about the intrinsic nature of the world in which Amerindians live-at least if we take "intrinsic" to mean "independent of an experiencing subject." On the contrary, Viveiros de Castro is interested in how the experienced world of Amerindians is different from the world of Western (or Westernized) individuals: how that world is set up differently so that, for example, humans did not evolve from animals (as Western modernity has it), but rather animals evolved from humans. As Viveiros de Castro puts it pithily, "Humans are those who continue as they have always been: animals are exhumans, not humans ex-animals" (472). For Viveiros de Castro, this difference is so radical that it cannot be accounted for as a mere cultural difference, because the word "culture" itself is deeply implicated in Western dichotomies. Another term is needed to capture this categorical difference, and ontology, for proponents of the ontological turn, does the trick (for further discussion, see Heywood).

While anthropologists continue debating the merits of the ontological turn, it is noteworthy that this discussion troubles the boundary between epistemology and the standard, metaphysical meaning of the word "ontology." The world is not something "out there," ready to be either understood as a standalone object (ontology) or correlated to a human subject (which would be epistemology). Rather, the world is constructed by a subject in conjunction with a certain material environment as well as a cultural context (Amerindian cultures, in Viveiros de Castro's example). The dualistic bifurcation between world and subject-arguably, one of the key assumptions of Western thinking-vanishes. This critique of bifurcation emerges, in various forms, in several contemporary movements or lines of thinking: from the account of the world as differently "enacted" by each living organism in Varela, Thompson, and Rosch's The Embodied Mind to philosophical work that, in a more or less explicitly ecological vein, seeks to challenge the separation of human subjectivity and material realities (Bennett; Shaviro). ${ }^{2}$ The kind of "world" we live in reflects our cognitive make-up and conceptual or cultural categories, so that-for instance-people in the West will tend to draw a clear-cut distinction between the human and the animal domain, without the reversibility of human and nonhuman perspectives that-to draw again on Viveiros de Castro's work-defines Amazonian ontology.

If we accept this use of the word "ontology," the problem becomes how to bridge between worlds in the absence of an objectively existing and externally stable reality. Drawing on Buddhist philosophy in 
the Mahayana tradition, Varela et al. employ the phrase "laying down a path in walking" (237) to describe the process of enacting a world that is not given out there-a "groundless" world, in their terminology. ${ }^{3}$ These phrases suggest how precarious and unstable ontological processes are in the absence of a metaphysical substrate for both the subject and material things: as Lieven Ameel's article in this special issue also shows, challenging bifurcation involves embracing the processual nature of reality and realizing that the (human) subject is entangled with its environment at a fundamental level-an unsettling idea for most individuals socialized into a Western ontology.

Philosophically, one could arrive at this ontological destabilization of the subject from many directions, all of which are of considerable relevance to the present moment (and to the debate staged by this special issue). One could argue, with Thomas Nagel, that the "materialist" worldview of Western science-which aims to shoehorn subjectivity into realities describable through the physical sciences-is deeply misguided. One could look to non-Western ontologies, as Viveiros de Castro does, or build on ideas growing out of so-called New Materialism (see Coole and Frost) and the nonhuman turn (Grusin) to claim that the seemingly autonomous subject is bound up, at multiple levels, with nonhuman organisms and processes, from the bacteria in our guts to the material implements that allow for the linguistic and narrative expression of subjectivity. The stability of the subject is coming under attack on many fronts. This essay traces the repercussions of this ontological disruption in contemporary fiction. I argue that the bifurcation between subjectivity and materiality is repeatedly and pointedly challenged by a strand of contemporary novels and short stories that foreground ontological questions. My use of the word "ontological" is aligned with the anthropological discussions I mentioned above: it doesn't refer to traditional subject-object metaphysics, but to the conceptual coordinates that allow us to lay down paths in walking - to enact a world that does not pre-exist our cognitive and cultural milieu. While these concerns are shared by philosophically engaged fictions in the contemporary context, I turn to Ali Smith's novel How to Be Both to explore this notion of groundless subjectivity and how it can foster, instead of disrupting, intersubjective communication. ${ }^{4}$ Before that, however, I want to demarcate this ontological dimension of twenty-first-century fiction from what Brian McHale has characterized as the "ontological dominant" of postmodernist fiction (see the "Introduction" to this special issue).

\section{A Tale of Two Ontologies}

Subjects were, of course, unstable well before the twenty-first century. A great deal of poststructuralist, psychoanalytic, and postcolonial thinking has disrupted and destabilized a unified and autonomous image of the human subject. Scholars working in these areas argued forcefully that the quintessentially Western concept of subjectivity swept under a universalist rug the vast socio-economic differences between those in a position of power and marginalized individuals. ${ }^{5}$ Yet many of these discussions remained locked within a view of the subject that, by and large, saw verbal language as the primary route into the failures and discontinuities of subjectivity. This tendency to frontload language reflects the structuralist roots of this style of thinking, since structuralism was-essentially-a philosophy of how verbal language is organized. ${ }^{6}$ As we move from the heyday of poststructuralism into the $1990 \mathrm{~s}$, this emphasis on language gives way to a different set of concerns having to do with the nonverbal and material origins of the human subject. In theorists like Donna Haraway (Simians, Cyborgs and Women) and Katherine Hayles this idea is pursued through an interest in computer technologies and how they augment or even replace the human subject. In the field of animal studies, it is the biological rootedness of mind that comes to the fore as we confront nonhuman subjectivities that are different from our own, and yet linked to it through a largely shared evolutionary history. In work inspired by Bruno Latour's 
Actor-Network-Theory, agency-a key attribute of the traditional humanist subject-is distributed across material assemblages that involve people, machines, as well as socio-cultural structures. Meanwhile, and partly in the wake of Varela, Thompson, and Rosch's already mentioned The Embodied Mind, the cognitive sciences have been foregrounding the embodied underpinnings of human psychology-how even advanced linguistic and conceptual skills are grounded in patterns of physical interaction with the material world; the mind is "world-involving," in Daniel Hutto's (43) phrase, in that it makes use of artifacts and material features of the environment to express and extend itself. These disparate approaches converge on what I presented above as the rejection of the mind-world bifurcation. By contrast, that bifurcation is still surreptitiously active in the poststructuralist emphasis on the connection between language and subjectivity. Put baldly: while the poststructuralist subject collapses under its own linguistic weight (and thus remains implicitly distinct from a nonverbal world "out there"), the material, embodied, and posthuman subject is questioned through becoming assimilated in or entangled with a vast gamut of material realities.

My central hypothesis is that these divergent routes to an unstable subject elicit profoundly different responses in postmodernist and twenty-first-century fiction, even as the spark of those responses (the breakdown of subjectivity) shares some broad similarities. This difference results in the "tale of two ontologies" hinted by the title of this section. Postmodernist fiction integrates the failures of the poststructuralist subject, along with its logic of linguistic bifurcation. What McHale characterizes as the ontological dominant of postmodernist fiction is an outward projection of this linguistically disrupted subject: under attack, the subject playfully or traumatically envisions an ontological plurality that remains nevertheless distinct from its own verbalizing nature. A particularly convincing discussion of this ontological productivity of the poststructuralist subject can be found in Debra Malina's Breaking the Frame. Malina singles out metalepsis - the blurring of narrative boundaries-as a formal device that suggests the collapse of a coherent subject in postmodernist texts. Examining Samuel Beckett's late works (particularly Company and Worstward Ho) in a postmodernist vein, Malina argues: "Sure, Beckett's narratives seem to say, try stepping outside of the narrative. Where do you find yourself? In another narrative, another narrative about narrative, about trying to reach the end of narrative-in effect, in the same narrative, through which you write yourself a life about trying to write yourself to death" (27). The multiplication of narratives is also, of course, a multiplication of worlds realized through the metaleptic erosion of ontological distinctions between reality and fiction. But this ontological impasse flows from the fact that, according to Malina's reading of Beckett, "the human condition is a written condition" (25)-a prototypically poststructuralist move. From this standpoint, the ontological play of postmodernist fiction is a reaction to the failures of the linguistic subject.

The strand of contemporary fiction I am interested in engages in a profoundly different kind of ontological experiment. Here "stepping outside of the narrative" does not reveal an infinite regress of linguistic narrativity, but rather uncovers a materiality-variably conceptualized in technological or biological terms - with which the subject was always already enmeshed. This materiality is not mere "matter" - it isn't a stable ontological ground, it is a relational property that arises from the interaction between living organisms, their biological and cultural history, and the physical environment. ${ }^{7}$ Of course, materiality can only be evoked obliquely in the language-based medium of fiction, through the slippages and hesitations of linguistic representation. Importantly, this implication of materiality undercuts the bifurcation of subject and world, and with it a set of related binary distinctions that underlie Western ontologies: mind and body, culture and nature, animate agents and inert matter. This shift can be 
described as follows: in postmodernist fiction, the destabilization of external reality is only a projection of a verbally unstable subject; in a significant strand of contemporary fiction, the subject and the world are jointly disrupted, and in some sense merged, as they are both revealed to be without a stable ontological ground. (Note that I am not describing the latter as a "dominant" of twentieth-first-century fiction, only as an important concern.) The rejection of bifurcation is never an entirely linear or unproblematic affair, of course. Fiction, like narrative in general, takes its cue from common-sense distinctions that are built into the Western cultural and linguistic system - for instance, distinctions between agency and passivity, or living bodies and inanimate entities. ${ }^{8}$ Troubling these ontological distinctions takes time, effort, and the willingness to confront an inherently unstable reality. As the subject-world divide collapses, fiction faces the failure of basic phenomenological intuitions-how "we" are distinct from reality "out there."

In this process, new possibilities for fictional writing come into view. The human subject can be transcorporeally extended into the material world, a fantasy of merging with the environment that informs, for instance, the works of Dutch-born Anglophone writer Michel Faber. ${ }^{9}$ In Faber's The Book of Strange New Things (2014), the protagonist visits a far-off planet, where his "body felt free and unencumbered, almost a part of the atmosphere, with no division between his skin and the surrounding sky" (431). In works by Kazuo Ishiguro (Never Let Me Go, 2005) and Jeanette Winterson (The Stone Gods, 2007), it is the dialog with, respectively, artificial intelligence and biotechnologies that reveals the fragility of the boundary between subjectivity and materiality. Richard Powers's fiction has also explored the questions arising from the integration of human psychology into a more-than-human world, with explicit environmental overtones in his recent The Overstory (2018). In Alexis Wright's The Swan Book (2013), similar ontological anxieties are channeled by the encounter, rich in political implications, of Western cultural references and Aboriginal mythology. These are only a few of the contemporary Anglophone authors who engage in an imaginary reshuffling of Western ontology, simultaneously "ungrounding" the subject and the world to reveal their fundamental entanglement.

These works are also particularly sensitive to the ethical ramifications of this entanglement. In a theoretical vein, writers like Karen Barad, Donna Haraway (Staying with the Trouble), and Deborah Bird Rose have discussed the ethics of living in an ontologically unstable world. Drawing a parallel with traditional Aboriginal dance, Rose uses the kinetic term "flip" to refer to the flux of life and death in a world where human and nonhuman subjects and the environment are ecologically enmeshed. ${ }^{10}$ Rose then switches metaphors and describes the "flip" of Aboriginal dance as "iridescent" - another figure of instability. ${ }^{11}$ The passage is worth quoting in full:

Flips appear at first to be either/or: either this foreground or that foreground. But for participants, the patterns are experienced in the body and in time. One is experiencing both flow and simultaneity, and iridescence arises in the patterns of mutual copresence. Iridescence is the point at which the either/or is experienced as both/and. In thinking about life and death, we encounter just such an iridescence, a shimmer arising from Earth life. Time and multiplicity move us into flow. (136-37)

Rose's ethics of "ecological existentialism" embraces this iridescence, these constant flips that suggest the precarity of the subject-our own human subject, in the face of the ecological crisis, but also of the nonhuman subjects that are being wiped out as a result of anthropogenic habitat loss and human industrial activities. Responsibility toward our own species and other life forms derives from awareness 
of unstable but pervasive connection. Contemporary fiction speaks directly to this sense of ethical entanglement, in a way that-as has been noted multiple times-marks another sharp departure from postmodernist fiction. ${ }^{12}$ Already from the title, Ali Smith's How to Be Both accommodates the iridescence-an experience of "both/and," in Rose's words - that Rose presents as the centerpiece of her ecological ethics. As we'll see, in Smith's work the ontological instability of the subject is also yoked together with ethical questioning.

\section{Facing Up to Uncertainty and Grasping Nonhuman Materiality in How to Be Both}

Ali Smith's novel consists of two parts, one focalized by George (short for Georgia, a teenager in contemporary Britain), the other narrated by Francescho (a fictionalized version of Francesco del Cossa, one of the major painters of the Ferrarese school in Renaissance Italy).${ }^{13}$ Unusually, both chapters are titled "One," and in fact their order isn't fixed: in my copy of How to Be Both, the George section precedes the Francescho section, whereas other copies invert that order, which makes for a significantly different reading experience-a first indication of how the materiality of the book's presentation shapes our interpretation of and responses to the protagonists. How to Be Both focuses on the parallel lives of George-a purely fictional being-and Francescho, a historical figure whom Smith reimagines as a woman under disguise. Separated by five centuries as well as language and cultural context, the characters are brought together in a manner that is oblique and allusive rather than straightforwardly diegetic. In the George section, we see the girl becoming acquainted with Francescho's work during a trip to Ferrara with her mother, and particularly after seeing her frescoes in the fifteenth-century Palazzo Schifanoia. Recollecting that visit after her mother's sudden death, George develops an imaginary intimacy with Francescho and a passion for her works, which help her cope with grief. At the end of this half of the novel, George travels to London to see the only work of Francescho on display at the National Gallery, a panel with San Vincenzo Ferrer. It is while contemplating Francescho's work that George encounters, by coincidence, a mysterious woman her mother has had a relationship with before her premature death.

The Francescho section contains a fictionalized retelling of her life, including historical details such as her rivalry with Cosimo Tura, an established court painter in Ferrara, and her abrupt departure from the Este court after being denied what she considered fair remuneration by the Duke Borso d'Este. Intermixed with these historical facts, which reflect essentially all we know about Francesco del Cossa's biography, is Smith's invention: Francescho is actually a woman and she wakes up, post-mortem, in twenty-first-century London, where the present of her narrative is located. At first, Francescho's consciousness appears in the National Gallery near the San Vincenzo Ferrer altarpiece: the first thing she sees is George's back as she observes the painting. But when George returns to the museum repeatedly and starts spending hours watching Francescho's panel, the painter's ghostly consciousness decides to follow her as she attempts to find out more about her mother's friend. This is where the two characters' lives converge, even if George is never named explicitly in the Francescho sections (though her identification with the "girl" observed by Francescho is strongly implied). Of course, the exact timing of the identification depends on the order in which the two sections appear in the particular copy of the book we are reading: if the George section comes first (as it does in my edition), the reader will easily draw a connection between the anonymous girl of the second half and the protagonist of the first half; if, on the other hand, the Francescho section comes first, the narrative is likely to prove more challenging and the identification of the girl will require some backtracking after the reader has become familiar with George and her story in the second half. 
The problem at the heart of How to Be Both, as the title already implies, is how to imagine ourselves into a subjectivity separated from ours by a significant historical and cultural gap-a problem that readers share with the two protagonists as they slowly (and largely indirectly) get to know each other. If enacting a world involves laying down a path in walking, as Varela, Thompson, and Rosch suggest, the imaginative exercise Smith's book asks us to perform can perhaps be compared to building a bridge in crossing: we are invited to draw connections between George and Francescho at the same time as we engage with their evolving voices and consciousnesses-without any external viewpoint that could provide distance and "ground" for the comparison. At first, George seems rather pessimistic about the chances of success of that operation. Asked by her school teacher to "give a three-minute talk about empathy," George hesitates and then blurts out "some things her mother was always saying about how near-impossible it was to inhabit anyone else's shoes, whether they lived in Paraguay or just down the road" (77). However, as George learns to coexist with the shock of her mother's death, that pessimistic view gradually gives way to a sense of imaginative and ethical openness that constitutes the premise for the sharing of experiences with Francescho, despite the historical gap separating them.

Enabling this transcultural dialogue are two parallel conceptual dynamics, which emerge in both halves of the novel and drive George's psychological trajectory: I call them, with deliberately embodied imagery, "facing up to uncertainty" and "grasping nonhuman materiality." George's world, recently shaken by her mother's death, is marked by a deep sense of uncertainty. This temporal and existential groundlessness becomes particularly painful because, as the novel suggests, George's reality (which is also the contemporary reader's everyday reality) is ill at ease with mystery and uncertainty:

The mysterious nature of some things was accepted then [in ancient times], much more taken for granted, Mrs Rock [George's mental-health counselor] said. But now we live in a time and in a culture when mystery tends to mean something more answerable, it means a crime novel, a thriller, a drama on TV, usually one where we'll probably find out-and where the whole point of reading it or watching it will be that we will find out-what happened. (72; emphasis in the original)

Used to the short-lived mysteries and quick resolutions of today's mass media, George struggles with uncertainty of a deeper, existential nature-the kind of uncertainty with which Smith confronts the reader by leaving George's and Francescho's intertwined stories suspended the end of the novel. George's psychological trajectory involves learning to turn her anxieties into an appreciation of openended mysteries. The last scene of her half of the novel strongly suggests that George's attitude toward mystery has changed. At the National Gallery, George unexpectedly runs into her mother's enigmatic friend. A three-page sequence, cast in the future tense, narrates George's attempts to know more about this woman. ${ }^{14}$ Suddenly, the sequence is interrupted by the words: "none of the above has happened. Not yet, anyway. For now, in the present tense, George sits in the gallery and looks at one of the old paintings on the wall. It's definitely something to do. For the foreseeable" (185-86). The omission of the word "future" in this last sentence of the George section indicates a dramatic shift in the protagonist's sense of mystery, a serene "taking for granted" (to paraphrase Mrs. Rock) of an unstable futurity. It is this acceptance of uncertainty that enables a peaceful inhabiting of the present.

This ending would be impossible without George's encounter with Francescho. Her final embrace of ontological instability is facilitated by Francescho's story, which brings in a radical reshuffling of the ontological categories of science-infused Western modernity. Francescho's premodern world is deeply 
informed by organic images that constantly blur the distinction between human life and nonhuman materiality. In a motif from one of Francescho's works that recurs multiple times in the novel, Saint Lucy's eyes are mounted on what looks like a vegetal stalk. The motif also serves as a visual emblem of the Francescho section, distinguishing it from the George section (prefaced by a stylized surveillance camera; see Figure 1). Francescho's mind brims with traces of nonhuman vitality-vibrant matter, in Jane Bennett's phrase-that flow directly into her paintings: "What's got into you? my father said cause all I could think of all that week was flowers for breath and flowers for eyes and mouths full of flowers, armpits of them, the backs of knees, laps, groins overflowing with flowers and all I could draw was leaves and flowers, the whorls of the roses, the foliage dark" (272). Art collapses distinctions between the human subject and the nonhuman world-which are joined, for Francescho, by a sense of effortless creativity. This ontological convergence is what George learns from her intimacy with Francescho, and what the reader may also learn by drawing connections between the novel's halves.

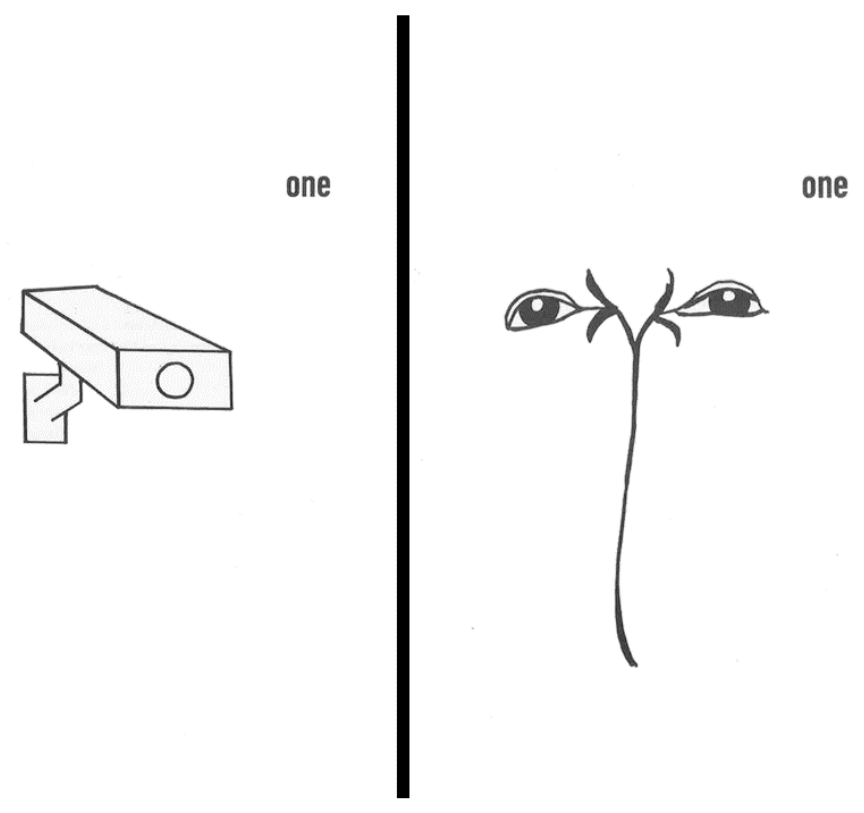

Figure 1 The camera and eye emblems that preface the two parts of How to Be Both.

Throughout the novel, and especially in the Francescho section, the implication of the subject in nonhuman materiality reveals itself in markedly embodied terms. While Deborah Bird Rose favors the kinetic image of the "flip" for the ecological patterning of life and death, Smith adopts a different-but related-metaphor, that of the "twist." ${ }^{15}$ This image works at several levels in the novel, from the thematic to the narratological, conceptual, and even typographical. Thematically, the twist becomes associated with the helix of DNA. While revising for a biology test, George and her friend Helena playfully rewrite the lyrics of the 1960s song "Let's Twist Again" as "Let's helix again, like we did last summer," adding "(Helix : Greek for twist)" (170; emphasis in the original). The twist-helix thus becomes the spatial form of the materiality of life and subjectivity. But the twist is also, narratologically, the hinge of the two parallel lives related by Smith's novel, their surprising point of convergence as we realize that George is the girl to which Francescho's ghostly presence becomes attached. This twist bears a 
superficial resemblance to what Cornelia Klecker calls "mind-tricking narratives," with Chuck Palahniuk's Fight Club as an example: in this scenario, readers are first tricked into believing that (for example) a character is real, until a surprising revelation forces them to revise their understanding of the plot (the character becomes a figment of the narrator's imagination). Yet Smith's narrative twist differs from Klecker's tricks in that it is reversible (as the free order of the two chapters also makes clear): the twist doesn't impose on readers a new understanding but invites them to shuttle back and forth between two worlds - to be both George and Francescho, in other words.

Indeed, the twist is the conceptual move required, on the reader's part, to connect these distant characters and grasp how Francescho's premodern fascination with nonhuman materiality comes to infiltrate George's world and reshape her ontology. Finally, and perhaps most strikingly, the twist is visually (that is, typographically) rendered in Smith's novel at the beginning and at the end of the Francescho section. Here the layout of the page recalls the spiral-like form of DNA, with the "twist" being foregrounded by the first line of text:

Ho this is a mighty twisting thing fast as a

fish being pulled by its mouth on a hook

if a fish could be fished through a

6 foot thick wall made of bricks or an

arrow if an arrow could fly in a leisurely

curl like the coil of a snail or a

star with a tail if the star was shot

upwards past maggots and worms and

the bones and the rockwork as fast

coming up as the fast coming down

of the horses in the story of

the chariot of the sun when the

bold boy drove them though

his father told him not to and

he did anyway and couldn't hold them. (189)

This twisting text opens and closes the Francescho section, ostensibly narrating how the consciousness of a fifteenth-century Italian painter was captured-like the "fish . . on a hook" of the second line-and hurled into the world of a twenty-first-century British woman. Through this multimodal device, the nonhuman materiality that occupies the thematic foreground of the narrative is inscribed into, and blended with, the material form of language, with human subjectivity-in this case, Francescho's but also potentially George's and the reader's-becoming part of the pattern traced by the text. ${ }^{16}$ The final lines explicitly draw attention to the ontological dimension of this poetic ending: "hello all the new bones / hello all the old / hello all the everything / to be / made and / unmade / both" (372). The language of "everything" being "made and unmade both" takes us remarkably close to the flux of life and death outlined by Rose's ecological existentialism. The vitalistic ontology of Francescho's world evokes a sense of radical entanglement with a more-than-human world where subjectivity is only one aspect of the cycle of things being "made and unmade." ${ }^{17}$ Crucially, this unstable ontology ties in with a sense of ethical responsibility toward the (human or nonhuman) other-an embrace of our precarious position in the fold of history. As the reader will recall, George comes to value the mystery of her future 
on a personal and also existential level: the unexplained intimacy between George and Francescho becomes bound up with that broader mystery. Through the premodern ontology that Francescho brings into George's world, their connection serves as a template for understanding the linkage of an unstable subject with a groundless world: how to be both a phenomenological subject and embedded in material reality.

\section{Conclusion}

The starting point of this article was a seminal debate in anthropology that highlighted the difficulties involved in using words like ontological and ontology in a non-dualistic manner-that is, without introducing a bifurcation of subjectivity (the realm of epistemology) and the world "out there" (the realm of ontology in the metaphysical sense). Claiming that ontology is "just another word for culture," as some of the scholars at the Manchester debate insisted, means downplaying the way in which conceptual categories shared within a certain community help us enact (in the sense of co-create) a world that does not dualistically pre-exist our interactions. This view of ontology as the result of an encounter between an embodied organism and its material and cultural milieu is emerging in numerous areas of contemporary thought, from enactivist approaches to cognition to work within New Materialism and the nonhuman turn. While I could only touch briefly on these philosophical movements in this article, and I could not do justice to the disagreements between them, I have focused on what I take to be their two common denominators: a notion of groundless ontology, whereby subject and world arise "codependently" (to lift Varela, Thompson, and Rosch's term), and an interest in embracing and valuing the resulting instability rather than falling back on a metaphysical substrate. This ontological view clashes with many binary assumptions of Western modernity.

I have argued that a significant strand of twenty-first-century fiction integrates and responds to the challenge of this groundless ontology through stylistic and narrative means, and that this engagement can help differentiate contemporary literary practices from postmodernist ones. In broad strokes, the ontological play of postmodernist authors takes place within a linguistic echo chamber that destabilizes the Western subject but does not significantly reach toward nonhuman materiality. By contrast, as my analysis of How to Be Both has suggested, contemporary fiction displaces the subject by emphasizing its ontological and ethical entanglement with materiality conceived of in physical, biological, or technological terms. How to Be Both illustrates the tensions that are generated when a common-sense understanding of subjectivity is destabilized via biology (the form of DNA) and a premodern ontology (Francescho's vitalism). These tensions ripple across the novel, from the typographical to the narratological and conceptual levels. Similar effects can be found in other contemporary works that address computer technology, artificial intelligence, as well as the threat of climate change, as I could only show in passing (but as this special issue as a whole demonstrates). This strand of philosophically engaged fiction incorporates, and seeks to lend literary form to, the existential anxieties that derive from the ontological precariousness of the human. In some instances, the aim of this literary operation may be akin to an imaginary resolution of these anxieties; however, as Smith's novel implies, and as Porter Abbott has argued in a more theoretical mode, literature is at its best when it does not seek to dispel mysteries, but rather asks us to linger within them and welcome the instability of our knowledge.

\section{Works Cited}

Abbott, H. Porter. Real Mysteries: Narrative and the Unknowable. Ohio State University Press, 2013. 
Alaimo, Stacy. Bodily Natures: Science, Environment, and the Material Self. Indiana University Press, 2010.

Armstrong, Nancy. "The Affective Turn in Contemporary Fiction." Contemporary Literature, vol. 55, no. 3, 2014, pp. 441-65.

Barad, Karen. Meeting the Universe Halfway: Quantum Physics and the Entanglement of Matter and Meaning. Duke University Press, 2007.

Bennett, Jane. Vibrant Matter: A Political Ecology of Things. Duke University Press Books, 2010.

Boxall, Peter. Twenty-First-Century Fiction: A Critical Introduction. Cambridge University Press, 2013.

Caracciolo, Marco. The Experientiality of Narrative: An Enactivist Approach. de Gruyter, 2014.

---. "Ungrounding Fictional Worlds: An Enactivist Perspective on the 'Worldlikeness' of Fiction." Possible Worlds Theory and Contemporary Narratology, edited by Alice Bell and Marie-Laure Ryan, University of Nebraska Press, 2019, pp. 113-31.

Caracciolo, Marco, and Shannon Lambert. "Narrative Bodies and Nonhuman Transformations." SubStance, vol. 48, no. 3, 2019, pp. 45-63.

Carrithers, Michael, et al. "Ontology Is Just Another Word for Culture: Motion Tabled at the 2008 Meeting of the Group for Debates in Anthropological Theory, University of Manchester." Critique of Anthropology, vol. 30, no. 2, 2010, pp. 152-200.

Coole, Diana, and Samantha Frost, editors. New Materialisms: Ontology, Agency, and Politics. Duke University Press, 2010.

Debaise, Didier. Nature as Event: The Lure of the Possible. Translated by Michael Halewood, Duke University Press, 2017.

Faber, Michel. The Book of Strange New Things. Hogarth, 2014.

Gibbons, Alison. "Multimodal Literature and Experimentation." The Routledge Companion to Experimental Literature, edited by Joe Bray et al., Routledge, 2012, pp. 420-34.

Goatly, Andrew. "Green Grammar and Grammatical Metaphor, or Language and the Myth of Power, or Metaphors We Die By." Journal of Pragmatics, vol. 25, no. 4, 1996, pp. 537-60.

Grusin, Richard, editor. The Nonhuman Turn. University of Minnesota Press, 2015.

Haraway, Donna. Simians, Cyborgs and Women: The Reinvention of Nature. Routledge, 1991.

---. Staying with the Trouble: Making Kin in the Chthulucene. Duke University Press, 2016.

Hayles, N. Katherine. How We Became Posthuman: Virtual Bodies in Cybernetics, Literature, and Informatics. University of Chicago Press, 1999.

Heywood, Paolo. "The Ontological Turn." Cambridge Encyclopedia of Anthropology, May 2017, http://www.anthroencyclopedia.com/entry/ontological-turn. 
Holbraad, Martin. Truth in Motion: The Recursive Anthropology of Cuban Divination. University of Chicago Press, 2012.

Hutto, Daniel D. "Exposing the Background: Deep and Local." Knowing without Thinking: Mind, Action, Cognition and the Phenomenon of the Background, edited by Zdravko Radman, Palgrave, 2012, pp. 3756.

Keller, Daniela. "Sensing I and Eyes in Ali Smith's How to Be Both." Diffractive Reading: New Materialism, Theory and Critique, edited by Kai Merten, Rowman \& Littlefield, forthcoming.

Klecker, Cornelia. "Mind-Tricking Narratives: Between Classical and Art-Cinema Narration." Poetics Today, vol. 34, no. 1-2, 2013, pp. 119-46.

Latour, Bruno. Reassembling the Social: An Introduction to Actor-Network-Theory. Oxford University Press, 2005.

Malina, Debra. Breaking the Frame: Metalepsis and the Construction of the Subject. Ohio State University Press, 2002.

McHale, Brian. Postmodernist Fiction. Routledge, 1987.

McLaughlin, Robert L. "Post-Postmodern Discontent: Contemporary Fiction and the Social World." Symploke, vol. 12, no. 1, 2004, pp. 53-68.

Morton, Timothy. The Ecological Thought. Harvard University Press, 2010.

Nagel, Thomas. Mind and Cosmos: Why the Materialist Neo-Darwinian Conception of Nature Is Almost Certainly False. Oxford University Press, 2012.

Rose, Deborah Bird. Wild Dog Dreaming: Love and Extinction. University of Virginia Press, 2011.

Shaviro, Steven. The Universe of Things: On Speculative Realism. University of Minnesota Press, 2014.

Smith, Ali. How to Be Both. Penguin Books, 2015.

Varela, Francisco J., et al. The Embodied Mind: Cognitive Science and Human Experience. MIT Press, 1991.

Viveiros de Castro, Eduardo. "Cosmological Deixis and Amerindian Perspectivism." The Journal of the Royal Anthropological Institute, vol. 4, no. 3, 1998, pp. 469-88.

Wolfe, Cary. What Is Posthumanism? University of Minnesota Press, 2010.

\footnotetext{
${ }^{1}$ While working on this article, the author received funding from the European Research Council (ERC) under the European Union's Horizon 2020 research and innovation program (grant agreement No 714166).

2 The term "bifurcation" derives from Alfred North Whitehead's process philosophy. For a recent reappraisal, see Didier Debaise's Nature as Event, which offers a helpful discussion of bifurcation (Debaise 5-15). Varela, Thompson, and Rosch's enactivism also underlies Merja Polvinen's contribution to this special issue.

${ }^{3}$ See Caracciolo ("Ungrounding Fictional Worlds") for an application of this idea of "groundless world" to narrative theory, as well as Caracciolo (Experientiality) for a more general, enactivist account of narrative.
} 
${ }^{4}$ Thanks go to Daniela Keller for bringing Smith's novel to my attention and for inspiring my analysis through her own, Karen Barad-inflected reading (Keller).

${ }^{5}$ For more on this entrenched idea of subjectivity, see Wolfe ("Introduction") and-with specific emphasis on contemporary fiction-Boxall (chap.3).

${ }^{6}$ See, however, the divergent position articulated by Pieter Vermeulen in his article for this special issue: for Vermeulen, linguistic metaphors-and particularly those that build on written language or Derridean écriture-still retain heuristic value in confronting nonhuman materiality.

${ }^{7}$ Karen Barad would prefer to use the term "intra-action" for this kind of constitutive interaction: "in contrast to the usual 'interaction,' which assumes that there are separate individual agencies that precede their interaction, the notion of intra-action recognizes that distinct agencies do not precede, but rather emerge through, their intraaction" (33).

${ }^{8}$ See Goatly for an insightful discussion of how the English language is grammatically biased toward dualism.

9 "Transcorporeality" is a concept introduced by Stacy Alaimo in Bodily Natures. For a discussion of three narrative motifs that enact transcorporeality, see Caracciolo and Lambert.

${ }^{10}$ The metaphor of enmeshment (for ecological interrelatedness) comes from Timothy Morton's work.

${ }^{11}$ In his article for this special issue, Lieven Ameel also discusses iridescence (via Roman Ingarden and Brian McHale), but then opts for the Deleuzian metaphor of the fold to steer clear of the on-off quality of iridescence, which contains traces of dualism.

${ }^{12}$ See Nancy Armstrong's account of the "affective turn" in twentieth-first-century fiction and also Robert McLaughlin on the return of social engagement.

${ }^{13}$ I adopt here Smith's archaic spelling "Francescho" to distinguish her fictional character from the historical painter. I also use feminine pronouns to refer to Francescho, in line with Smith's novel.

${ }^{14}$ For example: "She will track the woman, staying behind her ... all the way across London," etc. (184).

${ }^{15}$ This metaphor is at the center of Keller's reading of Smith's novel.

${ }^{16}$ Multimodality denotes the use of nonlinguistic elements (for instance, visual layout or material textures) in prose fiction. For more on multimodality, I refer to Alison Gibbons's work, including her contribution to this special issue.

${ }^{17} \mathrm{Cf}$. also the lines that precede the last quotation, which celebrate the creative potential of materiality in terms that collapse distinctions between the cosmic, the organic, and the human: "how / the root in the dark makes its / way under ground / before there's / any sign of the tree / the seed still unbroken / the star still unburnt / the curve of the eyebone / of the not yet born" (371-72). 